\title{
Universiteit
}

Leiden

The Netherlands

\section{Reconsidering research on teachers' professional identity}

Beijaard, D.; Meijer, P.C.; Verloop, N.

\section{Citation}

Beijaard, D., Meijer, P. C., \& Verloop, N. (2004). Reconsidering research on teachers' professional identity. Teaching And Teacher Education, 20, 107-128. Retrieved from https://hdl.handle.net/1887/11190

Version: $\quad$ Not Applicable (or Unknown)

License: $\quad$ Leiden University Non-exclusive license

Downloaded from: $\quad$ https://hdl.handle.net/1887/11190

Note: To cite this publication please use the final published version (if applicable). 


\title{
Reconsidering research on teachers' professional identity
}

\author{
Douwe Beijaard*, Paulien C. Meijer, Nico Verloop \\ ICLON_Graduate School of Education, Leiden University, P.O. Box 9555, 2300 RB Leiden, The Netherlands
}

Received 1 May 2002; received in revised form 17 June 2003; accepted 31 July 2003

\begin{abstract}
The studies considered in this review of recent research on teachers' professional identity can be divided into three categories: (1) studies in which the focus was on teachers' professional identity formation, (2) studies in which the focus was on the identification of characteristics of teachers' professional identity, and (3) studies in which professional identity was (re)presented by teachers' stories. In the studies reviewed, the concept of professional identity was defined differently or not defined at all. Four essential features of teachers' professional identity could be derived from the studies. Many of the reviewed studies appeared to be studies on teachers' personal practical knowledge. However, in only a few studies was the relationship between this knowledge and professional identity made explicit. It is argued that, in future research on teachers' professional identity, more attention needs to be paid to the relationship between relevant concepts like 'self' and 'identity', the role of the context in professional identity formation, what counts as 'professional' in professional identity, and research perspectives other than the cognitive one that may also play a role in designing research on teachers' professional identity.
\end{abstract}

(C) 2004 Elsevier Ltd. All rights reserved.

Keywords: Professional identity; Self; Reflection; Personal practical knowledge

\section{Introduction}

In the last decade, teachers' professional identity has emerged as a separate research area (e.g., Bullough, 1997; Connelly \& Clandinin, 1999; Knowles, 1992; Kompf, Bond, Dworet, \& Boak, 1996). To explain what this concept means, several authors have drawn on the definition of identity used in the social sciences and philosophy. Of particular interest in this regard is the work of the symbolic interactionist Mead (1934) and the

\footnotetext{
*Corresponding author. Tel.: +31-71-5274015; fax: + 31-715275242 .

E-mail address: beijaard@ICLON.leidenuniv.nl (D. Beijaard).
}

psychologist Erikson (1968). The latter focused on identity formation in social contexts and on the stages people pass through: owing to biological and psychological maturation, each stage has its own characteristics regarding the individual's interaction with his or her environment. Erikson outlined a chronological and changing concept of identity. Identity is not something one has, but something that develops during one's whole life. Mead used the concept of identity in relationship with the concept of self; he described in detail how the self is developed through transactions with the environment. According to Mead, self can arise only in a social setting where there is social communication; in communicating we learn to assume the roles of others and monitor our actions 
accordingly. Our concept of self can be defined as an organized representation of our theories, attitudes, and beliefs about ourselves (McCormick \& Pressley, 1997). The world of the self may appear to the outsider to be subjective and hypothetical, but to the individual experiencing it, it has the feeling of absolute reality (Purkey, 1970). In general, the concept of identity has different meanings in the literature. What these various meanings have in common is the idea that identity is not a fixed attribute of a person, but a relational phenomenon. Identity development occurs in an intersubjective field and can be best characterized as an ongoing process, a process of interpreting oneself as a certain kind of person and being recognized as such in a given context (Gee, 2001). In this context, then, identity can also be seen as an answer to the recurrent question: "Who am I at this moment?"

The concept of identity is defined in various ways in the more general literature. It seems that the concept of professional identity is also used in different ways in the domain of teaching and teacher education. In some studies, the concept of professional identity was related to teachers' concepts or images of self (e.g., Knowles, 1992; Nias, 1989). It was argued that these concepts or images of self strongly determine the way teachers teach, the way they develop as teachers, and their attitudes toward educational changes. In other studies of professional identity, the emphasis was placed on teachers' roles (e.g., Goodson \& Cole, 1994; Volkmann \& Anderson, 1998), whether or not in relationship with other concepts, or on concepts like reflection or self-evaluation that are important for the development of professional identity (e.g., Cooper \& Olson, 1996; Kerby, 1991). Furthermore, professional identity refers not only to the influence of the conceptions and expections of other people, including broadly accepted images in society about what a teacher should know and do, but also to what teachers themselves find important in their professional work and lives based on both their experiences in practice and their personal backgrounds (Tickle, 2000). Both sides of professional identity seem strongly interwoven, but have been differently emphasized by researchers. Knowles (1992), there- fore, characterized professional identity as an unclear concept in the sense of what, and to what extent, things are integrated in such an identity.

Thus, while it is clear that teachers' professional identity has emerged as a separate research area, it is, in our view, an area in which researchers conceptualize professional identity differently, investigate varying topics within the framework of teachers' professional identity, and pursue a diversity of goals. Against this background, we felt the need to gain greater insight into this research area and, through that, contribute to a better understanding of what professional identity entails in teaching and teacher education, stimulate the discussion about this topic, and help in designing future research. In order to realize this, we attempted to answer the following questions:

- What features are essential for research on teachers' professional identity?

- How can current research on teachers' professional identity be characterized?

- What problems need to be addressed in research on teachers' professional identity?

The answers to these questions are based on a review of the literature on teachers' professional identity in which we systematically analyzed how this concept was used in studies and ascertained what the results of these studies were. First, therefore, we present this review.

\section{Selection and analysis of studies about teachers' professional identity}

We confined our search for the relevant literature to the period 1988-2000, because it was in this period that teachers' professional identity emerged as a research area. We began with

(1) a general Web of Science search, resulting in 12 hits with 'professional identity' in the title and related to teachers and teacher education; and

(2) an ERIC search, resulting in 18 hits with 'professional identity' in the title and/or as a major identifier and related to teachers and teacher education ( 5 hits were the same as in the Web of Science search). 
In total, we collected 25 studies, three of which were not useful for our purpose (though listed in the search systems, these studies were not explicitly concerned with teachers' professional identity). After reading the remaining studies $(N=22)$, we consulted their lists of references and collected an additional group of studies. We also found some additional studies by accident. These studies were not listed in any formal search system but seemed important to us too. Particularly in literature reviews, which can draw on only small numbers of studies, this is a normal procedure to follow (Mertens, 1998).

We took the selected studies $(N=22)$ as the basis for our analysis. These studies were analyzed with regard to their (1) purpose, (2) definition of professional identity, (3) concepts related to this definition, (4) methodology, and (5) major findings. The same analysis was not done for the additional studies we collected. These studies were only used to add to findings based on the analysis of the first group of studies.

Based on their focus of attention, the studies we systematically analyzed can be divided into three categories:

(1) studies in which the focus was on teachers' professional identity formation;

(2) studies in which the focus was on the identification of characteristics of teachers' professional identity as perceived by the teachers themselves or as identified by the researchers from the data they collected;

(3) studies in which professional identity was (re)presented by teachers' stories told and written.

Below, we describe the results of our analysis of these three categories of studies.

\section{Teachers' professional identity formation}

Research on teachers' professional identity formation is seen as relevant to teacher educators and mentors in schools in order to better understand and conceptualize the support student teachers need (cf. Volkmann \& Anderson, 1998). Particularly student teachers' biographies and the beliefs that are determined by these biographies are conceived of as important constituents of teachers' professional identity formation (Knowles, 1992; Sugrue, 1997; see also Kelchtermans, 1994). From this perspective, Bullough (1997) wrote that

Teacher identity - what beginning teachers believe about teaching and learning as self-asteacher-is of vital concern to teacher education; it is the basis for meaning making and decision making. (...) Teacher education must begin, then, by exploring the teaching self (p. 21).

Research on teachers' professional identity formation also contributes to our understanding and acknowledgment of what it feels like to be a teacher in today's schools, where many things are changing rapidly, and how teachers cope with these changes. From this point of view, it is important to pay attention to the personal part of teachers' professional identity. What is found relevant to the profession, especially in light of the many educational changes currently taking place, may conflict with what teachers personally desire and experience as good. Such a conflict can lead to friction in teachers' professional identity in cases in which the 'personal' and the 'professional' are too far removed from each other.

In Table 1 we summarize the studies that focused on professional identity formation. This table is further explained and interpreted below.

\subsection{Purpose of the studies}

While the studies listed in Table 1 pursued different purposes, two common purposes can be identified. First, in some studies, the emphasis was on describing the process of identity formation, either of student teachers (Antonek et al., 1997; Volkmann \& Anderson, 1998) or of special groups of teachers, i.e., foreign-trained teachers who wanted to become teachers in the United Kingdom (Mawhinney \& Xu, 1997) and instructors who had not had any conventional teacher preparation (Goodson \& Cole, 1994). The study by Sugrue 
Table 1

Overview of the studies on professional identity formation

\begin{tabular}{lllll}
\hline Author and year & $\begin{array}{l}\text { Purpose of the } \\
\text { study }\end{array}$ & Definition of p.i. & Related concepts & Methodology
\end{tabular}

\begin{tabular}{lll}
\hline Goodson and Cole & $\begin{array}{l}\text { To describe the } \\
\text { socialization and } \\
\text { development of the }\end{array}$ & $\begin{array}{l}\text { p.i. is similar to } \\
\text { professional reality } \\
\text { and the }\end{array}$ \\
$\begin{array}{ll}\text { p.i. of instructors } \\
\text { who had not had }\end{array}$ & $\begin{array}{l}\text { construction of this } \\
\text { reality is an ongoing } \\
\text { any conventional } \\
\text { teacher preparation }\end{array}$ & $\begin{array}{l}\text { process of personal } \\
\text { and contextual } \\
\text { interpretation }\end{array}$
\end{tabular}

Gardner (1995)

To give a historical account of teacher training and how No explicit definition; p.i. this is related to p.i. to 'the profession'
Antonek,

McCormick, and Donato (1997)
To demonstrate the No explicit use of working portfolios as tools that facilitate reflection and the construction of a new p.i. and to present a theoretical framework to support this
Self-perception, roles, self-identity

resteridentity

A series of life history interviews with 7 teachers and bi-weekly group discussions throughout the period of the study

None

Open-ended interviews with 44 former school teachers born between 1888 and 1917

definition; p.i. is something that one shapes through (self-)reflection two foreign
Self (as teacher), reflection, personal and social history portfolios (conceived of as autobiographies) of language student teachers for meaningful themes
- Teachers' sense of a new p.i. depends on their notions of professional community

- The broader institutional context should facilitate the realization of teachers' personal and professional potential

- After teacher training, teachers' professional lives were stable (absence of need for change)

- Further professional development consisted of refinement of skills learned during initial training

- Both student teachers were successful, but followed different developmental paths

- Forming the self as teacher is a unique and complex process

- p.i. is shaped by a combination of many knowledge sources

- portfolios are adequate tools for constructing a p.i. 
Table 1 (continued)

\begin{tabular}{|c|c|c|c|c|c|}
\hline Author and year & $\begin{array}{l}\text { Purpose of the } \\
\text { study }\end{array}$ & Definition of p.i. & Related concepts & Methodology & Major findings \\
\hline Sugrue (1997) & $\begin{array}{l}\text { To gain insight into } \\
\text { the most formative } \\
\text { personal and social } \\
\text { influences on } \\
\text { student teachers' } \\
\text { p.i. by } \\
\text { deconstructing their } \\
\text { lay theories }\end{array}$ & $\begin{array}{l}\text { p.i. is part of a } \\
\text { discourse which is } \\
\text { open to continuous } \\
\text { redefinition rather } \\
\text { than a set of } \\
\text { essential } \\
\text { characteristics } \\
\text { which are common } \\
\text { to all teachers }\end{array}$ & $\begin{array}{l}\text { Images, biography, } \\
\text { image of teaching }\end{array}$ & $\begin{array}{l}\text { Analysis of } \\
\text { interview } \\
\text { transcripts of } 9 \\
\text { beginning student } \\
\text { teachers for } \\
\text { emerging themes }\end{array}$ & $\begin{array}{l}\text { - Student teachers } \\
\text { identified } \\
\text { features of } \\
\text { teaching } \\
\text { identities } \\
\text { - Lay theories } \\
\text { depend on } \\
\text { student teachers' } \\
\text { personalities but } \\
\text { are shaped by } \\
\text { many other } \\
\text { sources as well } \\
\text { - Student } \\
\text { teachers' p.i. is } \\
\text { tacit and varies } \\
\text { in form from } \\
\text { theories of } \\
\text { teaching }\end{array}$ \\
\hline $\begin{array}{l}\text { Mawhinney and Xu } \\
\text { (1997) }\end{array}$ & $\begin{array}{l}\text { To highlight key } \\
\text { themes in the } \\
\text { reconstruction of } \\
\text { the p.i. of foreign- } \\
\text { trained teachers }\end{array}$ & $\begin{array}{l}\text { No explicit } \\
\text { definition; p.i. is } \\
\text { similar to standards } \\
\text { that should be met } \\
\text { by teachers }\end{array}$ & None & $\begin{array}{l}\text { Etnographic } \\
\text { investigation of } 7 \\
\text { foreign-trained } \\
\text { teachers by } \\
\text { identifying } \\
\text { emergent themes } \\
\text { from observational } \\
\text { data, field notes, } \\
\text { and interviews }\end{array}$ & $\begin{array}{l}\text { - Candidates took } \\
\text { many initiatives } \\
\text { in upgrading } \\
\text { their } \\
\text { professional } \\
\text { skills } \\
\text { - Constructing a } \\
\text { new professional } \\
\text { identity as a } \\
\text { teacher in } \\
\text { English- } \\
\text { speaking } \\
\text { settings is a long } \\
\text { and slow } \\
\text { process }\end{array}$ \\
\hline $\begin{array}{l}\text { Volkmann and } \\
\text { Anderson (1998) }\end{array}$ & $\begin{array}{l}\text { To describe the } \\
\text { creation of p.i. as a } \\
\text { science teacher }\end{array}$ & $\begin{array}{l}\text { p.i. is a complex } \\
\text { and dynamic } \\
\text { equilibrium } \\
\text { between personal } \\
\text { self-image and } \\
\text { teacher roles one } \\
\text { feels obliged to play }\end{array}$ & $\begin{array}{l}\text { Roles, self, self- } \\
\text { image, personal self, } \\
\text { professional self }\end{array}$ & $\begin{array}{l}\text { Analysis of a year- } \\
\text { long teaching } \\
\text { journal of one } \\
\text { beginning science } \\
\text { teacher for } \\
\text { emerging themes }\end{array}$ & $\begin{array}{l}\text { In her struggle to } \\
\text { create a p.i., the } \\
\text { teacher was } \\
\text { confronted with a } \\
\text { series of teaching } \\
\text { dilemmas }\end{array}$ \\
\hline $\begin{array}{l}\text { Coldron and Smith } \\
\text { (1999) }\end{array}$ & $\begin{array}{l}\text { To take a position } \\
\text { in the debate about } \\
\text { p.i. by emphasizing } \\
\text { the tension between } \\
\text { the role of agency } \\
\text { and structure (the } \\
\text { socially 'given') }\end{array}$ & $\begin{array}{l}\text { p.i. is not fixed or } \\
\text { unitary; it is not a } \\
\text { stable entity that } \\
\text { people have but a } \\
\text { way to make sense } \\
\text { of themselves in } \\
\text { relation to other } \\
\text { people and contexts }\end{array}$ & $\begin{array}{l}\text { Social space, } \\
\text { traditions, } \\
\text { biography, social } \\
\text { structure, agency, } \\
\text { active location }\end{array}$ & $\begin{array}{l}\text { Theoretical analysis } \\
\text { and 'theorizing' }\end{array}$ & $\begin{array}{l}\text { p.i. of teachers } \\
\text { reflects the } \\
\text { landscape the } \\
\text { teacher is part of } \\
\text { p.i. is manifested } \\
\text { in classroom } \\
\text { practice and is, } \\
\text { to some extent, } \\
\text { unique }\end{array}$ \\
\hline
\end{tabular}


Table 1 (continued)

Author and year Purpose of the Definition of p.i.

Related concepts

Methodology

Major findings study

Dillabough (1999) To demonstrate that questions of gender and the history of male dominance in political thought are central to our understanding of the formation of p.i.

p.i. is never fixed or pre-determined, but arises out of the relationship between those who interpret and ascribe meaning to action, language, and everyday practice in varied social contexts and circumstances
Samuel and Stephens (2000)
To examine the fundamental relationship between the individual sense of self and the development of a p.i. in a rapidly changing educational environment
Self

Theoretical analysis illustrated with preliminary data from the author's own research

p.i. is a 'perlocated' understanding and acceptance of a series of competing and sometimes contradictory values, behaviors, and attitudes grounded in the life experiences of the self in formation
Self, cultural context, environment

Case study of two student teachers (in South Africa) professional
- Striving for uniformity and conformity threatens teachers' active location

- The current conception of the modern teacher as a rational and instrumental actor ignores the notion of the authentic and discursive self

- Concepts such as 'voice' and 'narrative' are important for theorizing the teaching 'self'

- The teaching self is also an 'embedded self' which makes p.i. a complex and multifaceted entity

- There is a tension between hope and ambition and what the teacher can achieve

- There are many competing influences on teachers' roles and identities in a changing world context

- Student teachers' experiences as school children influence the formation of their identities as teachers-intraining 
(1997) on personal and social influences on student teachers' professional identity formation also fits in this group of studies.

Second, the purpose of some other studies was to describe the tension between person and context in the process of professional identity formation: Coldron and Smith (1999) did this from a theoretical point of view and Samuel and Stephens (2000) from a practical point of view. The purpose of the latter study was to describe the professional identity formation of student teachers with 'traditional' backgrounds in a rapidly changing educational environment.

\subsection{Definition of professional identity}

Table 1 shows that, in three of the nine studies, no explicit definition of professional identity was given. In the studies that defined what professional identity entails, different aspects were highlighted. Most of the researchers saw professional identity as an ongoing process of integration of the 'personal' and the 'professional' sides of becoming and being a teacher. Goodson and Cole (1994), e.g., perceived teachers' identity development as rooted both in the personal and the professional. They wrote,

We consider teachers as persons and professionals whose lives and work are influenced and made meaningful by factors and conditions inside and outside the classroom and school (p. 88).

Professional identity is not a stable entity; it cannot be interpreted as fixed or unitary (Coldron \& Smith, 1999). It is a complex and dynamic equilibrium where professional self-image is balanced with a variety of roles teachers feel that they have to play (Volkmann \& Anderson, 1998). In this context, Coldron and Smith (1999) pointed to the tension between agency (the personal dimension in teaching) and structure (the socially 'given'). They wrote that being a teacher is a matter of the teacher being seen as a teacher by himself or herself and by others; it is a matter of arguing and then redefining an identity that is socially legitimated.
Cooper and Olson (1996) pointed to the fact that professional identity is multifaceted. Historical, sociological, psychological, and cultural factors may all influence the teacher's sense of self as a teacher. Furthermore, professional identity may consist of many sub-identities that may conflict or align with each other (Mishler, 1999). According to Mishler, it is better to recognize in the definition of identity that a plurality of subidentities exists. To give expression to this, Mishler used the metaphor of "our selves as a chorus of voices, not just as the tenor or soprano solist" (p. 8). Gee and Crawford (1998) stated that we can take on different identities, depending upon the social setting, yet there are relationships between these identities. Continuing the metaphor, it can be concluded that the better the relationships between the different identities, the better the chorus of voices sounds (see also McCarthey, 2001).

A final remark pertaining to the definition of professional identity concerns the emphasis in most of the studies on the 'personal' and an underestimation of the contextual side that plays a part in professional identity formation. Reynolds (1996) emphasized that what surrounds a person, what others expect from the person, and what the person allows to impact on him or her greatly affect his or her identity as a teacher. She noted that the teachers' workplace is a 'landscape' which can be very persuasive, very demanding, and, in most cases, very restrictive. Cooper and Olson (1996) also pointed to the limits to the range and type identities may take. Like Sugrue (1997), who pointed to the need of changing student teachers' lay theories, they ascribe this to the impact of the external knowledge, norms, and values that belong to the 'landscape'.

\subsection{Related concepts}

In definitions of professional identity, the concept of 'self', often combined with other concepts (see Table 1), appears to be essential. Volkmann and Anderson (1998) followed Kerby (1991), who wrote about the self as the implied subject. In Kerby's opinion, the self appears to be inseparable from a person's narrative or life story; through stories, a person generates a sense of self. These stories are based on experiences and, by 
telling these stories, either in writing or verbally, a person shapes his or her self. In this respect, 'reflection' is seen as a relevant concept. Antonek et al. (1997) identified reflection as a key component associated with the concept of self. In other words, it is impossible to speak about the self when there is no reflection. To develop the self as a teacher, Antonek et al. emphasized the need to develop reflective skills. Where some authors refer to reflection, others speak about self-reflection. Through self-reflection, (student) teachers relate experiences to their own knowledge and feelings, and are willing and able to integrate what is socially relevant into their images of themselves as teachers (Korthagen, 2001; Nias, 1989).

Roberts (2000) wrote about multiple selves with different voices of discourse: the personal, professional, and institutional. Roberts argued that

The notion of multiple selves and different ways of talking connect with current research on teacher socialization and professional identity, where induction into teaching is seen as similar to the process of learning to talk (p. 186).

The self can never be described without reference to those who surround it (Taylor, 1989). With this in mind, Dillabough (1999) wrote about the self that arises out of complex and meaningful social interactions with peers and other 'professionals' (see also Jeans, 1996). She criticized the dominant notion of professional identity that only requires teachers to respond to instrumental goals (e.g., transmission of knowledge and achieving good results) formulated by policy makers and/or an objective body of so-called 'experts'. When a teacher meets these goals, he or she is labeled as 'competent'. About this way of thinking, Dillabough wrote that

(...) A discursive notion of the teaching 'self' is lost, and the complexity of education and its socialising mechanisms remain unexplored (p. 378).

\subsection{Methodology}

In the studies listed in Table 1 different methods for the collection of data were used. These varied from open-ended (life history) interviews to specific teacher materials, such as portfolios and journals. The data collected were analyzed for emerging themes, either using phenomenographic procedures or in a more interpretative way. The studies can be best characterized as small-scale and in-depth. The overall impression is that the studies differ greatly in the way and the extent to which they explain and account for the methods and techniques used for both the collection and analysis of data.

\subsection{Major findings}

Student teachers can be equally successful in their professional identity formation although they follow different developmental paths (Antonek et al., 1997). This uniqueness of the process of identity formation is supported by the 'theoretical' findings of Coldron and Smith (1999), who pointed to the need for teachers to be active in this process. Based on their theoretical analysis, they stated that teachers should participate in dialogue, be aware of the many approaches and ways of doing things, be engaged with a range of resources, and share ideas so that they can locate themselves. Striving for uniformity and conformity, then, would threaten the teacher's active location in the process of professional identity formation. Dillabough (1999) concluded that the current conception of the teacher as a rational and instrumental actor ignores the notion of the authentic and discursive self.

Professional identity formation is a process involving many knowledge sources, such as knowledge of affect, teaching, human relations, and subject matter (Antonek et al., 1997). Student teachers' own lay theories should also be seen as such a source. Sugrue (1997) found that these lay theories begin with the student teachers' personalities, but that they are significantly shaped by (1) immediate family, (2) significant others or extended family, (3) apprenticeship of observation, (4) atypical teaching episodes, (5) policy context, teaching traditions, and cultural archetypes, and (6) tacitly acquired understandings. Lay theories are tacit or unarticulated and lead to forms of professional identity formation that differ from forms of professional identity formation derived 
from research-based theories of teaching. It is important to enhance student teachers' awareness of their own theories (Sugrue, 1997; see also Bullough, 1997). A (student) teacher's biography, then, is important in the process of identity formation. Knowles (1992) mentioned early childhood experiences, early teacher role models, previous teaching experiences, and significant or important people and significant prior experiences as relevant biographical categories.

Professional identity formation is often presented as a struggle because (student) teachers have to make sense of varying and sometimes competing perspectives, expectations, and roles that they have to confront and adapt to (Samuel \& Stephens, 2000; Volkmann \& Anderson, 1998; see also Bullough, Knowles, \& Crow, 1992; Roberts, 2000). For example, Volkmann and Anderson (1998), who examined the professional identity formation of one beginning science teacher, found that this teacher's images of teaching conflicted with more general expectations of what makes a professional teacher. The three dilemmas this teacher struggled with were (1) feeling like a student while being expected to act like a teacher, (2) wanting to care for students while being expected to be tough, and (3) feeling incompetent in her knowledge of chemistry while being expected to behave like an expert. The results described by Goodson and Cole (1994) also follow this line. They found that teachers' sense of developing a (new) professional identity was contextually dependent on their developing notions of the professional community. Based on this, they concluded that

In order for teachers to have opportunities to realize their individually-defined personal and professional potential, teaching and development need to be defined, interpreted, and facilitated within a broader institutional context (p. 102).

\section{Characteristics of teachers' professional identity}

Some studies in this category drew attention to specific issues related to teachers' perceptions of professional identity, such as the teaching of lowstatus subjects in schools (Paechter \& Head, 1996), increasing teachers' sense of professional identity to prevent burnout or attrition, e.g., by providing a sabbatical year (Gaziel, 1995; see also Moore \& Hofman, 1988), and male teachers' reasons for entering primary education (DeCorse \& Vogtle, 1997). Some other studies in this category indicated that it is important to benefit from teachers' perceptions of aspects of their professional identity, such as the subject they teach, their relationship with students, and interactions with colleagues. Knowledge of teachers' perceptions of aspects of their professional identity may, e.g., be useful in helping them to cope with educational changes (Beijaard, Verloop, \& Vermunt, 2000), and serve as a basis for institutional and educational innovations (Nixon, 1996) or cooperation with colleagues (Mitchell, 1997). The last group of studies in this category attempted to make explicit what the occupational group shares or should share. Siraj-Blatchford (1993), e.g., wanted to draw attention to what new teachers share and which is ignored by policy documents. Preuss and Hofsass (1991) argued that the implementation of a new role (teaching disabled students in 'normal' classrooms owing to governmental policy) should have implications for teacher education.

The studies on characteristics of professional identity are summarized in Table 2. This table is further explained and interpreted below.

\subsection{Purpose of the studies}

Most of the studies focused on understanding and describing teachers' perceptions of aspects of their professional identity in general or perceptions that are related to specific issues of their profession and that can enrich the debate on these issues. An example of a study on such an issue (see Table 2) is the study by DeCorse and Vogtle (1997) on the attitudes and perceptions of men choosing to enter elementary teaching despite the fact that the social perception of teachers in primary education relates to female characteristics of teaching. They argued that the induction of more males into primary education may not so much transform teaching as create a more balanced education for children. An 
Table 2

Overview of the studies on characteristics of professional identity

\begin{tabular}{|c|c|c|c|c|c|}
\hline $\begin{array}{l}\text { Author and } \\
\text { year }\end{array}$ & $\begin{array}{l}\text { Purpose of the } \\
\text { study }\end{array}$ & Definition of p.i. & Related concepts & Methodology & Major findings \\
\hline $\begin{array}{l}\text { Moore and } \\
\text { Hofman (1988) }\end{array}$ & $\begin{array}{l}\text { To examine the } \\
\text { hypothesis that a } \\
\text { strong p.i. will } \\
\text { block a tendency to } \\
\text { leave institutes of } \\
\text { higher education } \\
\text { and may coexist } \\
\text { with considerable } \\
\text { criticism of those } \\
\text { institutes }\end{array}$ & $\begin{array}{l}\text { p.i. is similar to the } \\
\text { extent to which } \\
\text { someone thinks of } \\
\text { his or her role as } \\
\text { important, } \\
\text { attractive, and in } \\
\text { harmony with } \\
\text { other roles }\end{array}$ & Job-satisfaction & $\begin{array}{l}\text { Survey questionnaire } \\
\text { among members of } \\
\text { two faculties }(N=247 \\
\text { and 112) }\end{array}$ & $\begin{array}{l}\text { Job-satisfaction owing } \\
\text { to needs of self-esteem } \\
\text { and self-actualization } \\
\text { overrules causes of } \\
\text { dissatisfaction owing } \\
\text { to working conditions } \\
\text { - p.i. predicts job- } \\
\text { leaving inclinations } \\
\text { - striving for quality by } \\
\text { the institute is } \\
\text { consistent with a } \\
\text { highly developed p.i. }\end{array}$ \\
\hline $\begin{array}{l}\text { Preuss and } \\
\text { Hofsass (1991) }\end{array}$ & $\begin{array}{l}\text { To describe the } \\
\text { extension of } \\
\text { teachers' } \\
\text { professional roles } \\
\text { (p.i.) with a new } \\
\text { one (teaching } \\
\text { disabled students } \\
\text { who are integrated }\end{array}$ & $\begin{array}{l}\text { No explicit } \\
\text { definition; p.i. is } \\
\text { similar to roles } \\
\text { which are } \\
\text { interpreted in terms } \\
\text { of knowledge and } \\
\text { skills teachers need } \\
\text { to possess }\end{array}$ & None & Theoretical analysis & $\begin{array}{l}\text { Social integration of } \\
\text { young people with special } \\
\text { needs as an educational } \\
\text { goal can only be reached } \\
\text { by reforming teacher } \\
\text { education and changing } \\
\text { teachers' p.i. }\end{array}$ \\
\hline
\end{tabular}

Siraj-Blatchford To show that new (1993)

Beijaard (1995)

To explore teachers' current perceptions of aspects of their p.i. and to describe prior events and experiences related to these perceptions
Teachers' sense or None perception of autonomy determines their p.i. and is also the key to understanding this identity

p.i. is dynamic; changes over time through relevant others, events and experiences; and can be represented by relevant features of the profession
Self-image, selfevaluation

.

Theoretical analysis

Teachers $(N=30)$ drawing story lines for each aspect of teaching and explaining high and low points in these lines

Survey questionnaire $(N=269)$ sent 3 months before teachers went on
Researchers have given too much support to the competency approach (which was proposed in 1992); they admit that their work has a profound effect on teachers' selfidentity and performance

- Teachers' current perceptions of their p.i. are positive

- Positive and negative influences on p.i. could be identified

- After years of serving, teachers tend to perceive their p.i. less positively

- On average, at the beginning of their careers, teachers perceive their p.i. as relatively low

Teachers who have been on sabbatical and who have allocated part of their time to training 
Table 2 (continued)

\begin{tabular}{|c|c|c|c|c|c|}
\hline $\begin{array}{l}\text { Author and } \\
\text { year }\end{array}$ & $\begin{array}{l}\text { Purpose of the } \\
\text { study }\end{array}$ & Definition of p.i. & Related concepts & Methodology & Major findings \\
\hline & $\begin{array}{l}\text { teachers' p.i. and } \\
\text { their job burnout } \\
\text { levels, their } \\
\text { intentions of } \\
\text { leaving the } \\
\text { workplace, and } \\
\text { their intentions of } \\
\text { leaving the } \\
\text { profession }\end{array}$ & & & $\begin{array}{l}\text { sabbatical and } 6 \\
\text { months after they } \\
\text { resettled in their jobs }\end{array}$ & $\begin{array}{l}\text { reported an improvement } \\
\text { in their p.i. }\end{array}$ \\
\hline Nixon (1996) & $\begin{array}{l}\text { To enrich the } \\
\text { debate on higher } \\
\text { education by } \\
\text { acknowledging } \\
\text { university teachers' } \\
\text { professional voice } \\
\text { about their own } \\
\text { occupation and p.i. }\end{array}$ & $\begin{array}{l}\text { No explicit } \\
\text { definition; p.i. is } \\
\text { something that } \\
\text { characterizes an } \\
\text { occupational group } \\
\text { with specific } \\
\text { working conditions }\end{array}$ & None & $\begin{array}{l}\text { Structured open-ended } \\
\text { interviews with } 30 \\
\text { higher education } \\
\text { lecturers in two } \\
\text { different institutes }\end{array}$ & $\begin{array}{l}\text { University teachers } \\
\text { profess and practice } \\
\text { values as an } \\
\text { occupational group } \\
\text { There is a coherent } \\
\text { professional } \\
\text { perspective on } \\
\text { teaching and learning }\end{array}$ \\
\hline $\begin{array}{l}\text { Paechter and } \\
\text { Head (1996) }\end{array}$ & $\begin{array}{l}\text { To explore how the } \\
\text { body is } \\
\text { incorporated in the } \\
\text { p.i. of teachers of } \\
\text { low-status school } \\
\text { subjects (design \& } \\
\text { technology and } \\
\text { physical education) }\end{array}$ & $\begin{array}{l}\text { No explicit } \\
\text { definition; p.i. is } \\
\text { similar to what } \\
\text { teachers themselves } \\
\text { see as important } \\
\text { for their profession }\end{array}$ & None & $\begin{array}{l}\text { Interviews with } \\
\text { department members, } \\
\text { observations of } \\
\text { meetings, and } \\
\text { consultation of school } \\
\text { documents; data } \\
\text { analysis occurred } \\
\text { according to } \\
\text { progressively focused } \\
\text { techniques which } \\
\text { allowed data collection } \\
\text { to be informed by } \\
\text { ongoing analysis }\end{array}$ & $\begin{array}{l}\text { - p.i. of teachers of low- } \\
\text { status subjects is } \\
\text { located by these } \\
\text { teachers in teaching in } \\
\text { general rather than in } \\
\text { their subject skills in } \\
\text { particular } \\
\text { teaching a marginal } \\
\text { subject can be a } \\
\text { constant fight against } \\
\text { gendered stereotypes }\end{array}$ \\
\hline $\begin{array}{l}\text { DeCorse and } \\
\text { Vogtle (1997) }\end{array}$ & $\begin{array}{l}\text { To gain insight into } \\
\text { the attitudes and } \\
\text { perceptions of men } \\
\text { who choose to } \\
\text { enter elementary } \\
\text { teaching }\end{array}$ & $\begin{array}{l}\text { No explicit } \\
\text { definition; p.i. is } \\
\text { derived from the } \\
\text { social perception of } \\
\text { an occupational } \\
\text { group }\end{array}$ & None & $\begin{array}{l}\text { In-depth, semi- } \\
\text { structured interviews } \\
\text { with } 11 \text { male teachers }\end{array}$ & $\begin{array}{l}\text { Most common reason for } \\
\text { being or becoming an } \\
\text { elementary teacher is the } \\
\text { direct contact with and } \\
\text { nurturing of children }\end{array}$ \\
\hline Mitchell (1997) & $\begin{array}{l}\text { To explore } \\
\text { teachers' } \\
\text { interpretations of } \\
\text { three aspects of p.i. } \\
\text { and to examine } \\
\text { how these } \\
\text { interpretations } \\
\text { present challenges } \\
\text { to increased teacher } \\
\text { collaboration }\end{array}$ & $\begin{array}{l}\text { No explicit } \\
\text { definition; it is } \\
\text { assumed that p.i. is } \\
\text { characterized by } \\
\text { relevant aspects } \\
\text { and that it is } \\
\text { shaped by the } \\
\text { subjective } \\
\text { meanings teachers } \\
\text { give to these } \\
\text { aspects }\end{array}$ & None & $\begin{array}{l}\text { In-depth interviews } \\
\text { with } 8 \text { recently retired } \\
\text { secondary level } \\
\text { teachers, analyzing } \\
\text { transcribed texts for } \\
\text { each teacher, and } \\
\text { identifying emergent } \\
\text { themes within and } \\
\text { across interviews }\end{array}$ & $\begin{array}{l}\text { Focusing on their } \\
\text { interactions with } \\
\text { colleagues, the } \\
\text { teachers highlighted } \\
\text { three aspects of p.i. } \\
\text { (representation, } \\
\text { preparation, } \\
\text { dedication) } \\
\text { - There is an absence of } \\
\text { a shared p.i. necessary } \\
\text { for collaboration with } \\
\text { colleagues which is a } \\
\text { prerequisite for the }\end{array}$ \\
\hline
\end{tabular}


Table 2 (continued)

\begin{tabular}{|c|c|c|c|c|c|}
\hline $\begin{array}{l}\text { Author and } \\
\text { year }\end{array}$ & $\begin{array}{l}\text { Purpose of the } \\
\text { study }\end{array}$ & Definition of p.i. & Related concepts & Methodology & Major findings \\
\hline & & & & & $\begin{array}{l}\text { implementation of } \\
\text { current reforms }\end{array}$ \\
\hline $\begin{array}{l}\text { Graham and } \\
\text { Young (1998) }\end{array}$ & $\begin{array}{l}\text { To explore and } \\
\text { elaborate on the } \\
\text { nature of English- } \\
\text { language arts } \\
\text { teaching and its } \\
\text { processes in a social } \\
\text { reconstructionist } \\
\text { perspective on } \\
\text { multicultural } \\
\text { education }\end{array}$ & $\begin{array}{l}\text { No explicit } \\
\text { definition; p.i. is } \\
\text { something that } \\
\text { characterizes the } \\
\text { ideal teacher }\end{array}$ & None & $\begin{array}{l}\text { The emphasis was on } \\
\text { excerpts taken from } \\
\text { transcripts of } \\
\text { instructor's reflections, } \\
\text { from student learning } \\
\text { logs, and from } \\
\text { interview data with } \\
\text { students }\end{array}$ & $\begin{array}{l}\text { Various student } \\
\text { backgrounds regarding } \\
\text { issues of culture provide a } \\
\text { rich source for quality } \\
\text { conversation, which can } \\
\text { lie close to the hart of } \\
\text { effective teaching and } \\
\text { thus contribute to } \\
\text { creating the p.i. of a } \\
\text { competent multicultural } \\
\text { teacher }\end{array}$ \\
\hline $\begin{array}{l}\text { Beijaard, } \\
\text { Verloop, and } \\
\text { Vermunt (2000) }\end{array}$ & $\begin{array}{l}\text { To describe how } \\
\text { teachers perceive } \\
\text { aspects of their p.i. } \\
\text { and by which } \\
\text { factors this is } \\
\text { influenced }\end{array}$ & $\begin{array}{l}\text { p.i. is related to } \\
\text { aspects of teaching } \\
\text { common to all } \\
\text { teachers at a } \\
\text { general level, } \\
\text { implying subject- } \\
\text { matter, didactic, } \\
\text { and pedagogical } \\
\text { expertise }\end{array}$ & $\begin{array}{l}\text { Self-image, self- } \\
\text { evaluation }\end{array}$ & $\begin{array}{l}\text { Survey questionnaire } \\
\text { among } 80 \text { experienced } \\
\text { secondary school } \\
\text { teachers representing } \\
\text { different subject areas }\end{array}$ & $\begin{array}{l}\text { Teachers perceive } \\
\text { their p.i. differently } \\
\text { - Teachers' p.i. changes } \\
\text { significantly over time, } \\
\text { depending on subject } \\
\text { area } \\
\text { - Factors that influence } \\
\text { teachers' perceptions } \\
\text { of their own p.i. are } \\
\text { seen as equally } \\
\text { important }\end{array}$ \\
\hline
\end{tabular}

example of a study on teachers' perceptions of aspects of their professional identity in general is the study by Beijaard et al. (2000). In this study they described teachers' perceptions of their subject-matter, didactic, and pedagogical expertise. It appeared that teachers perceived these aspects of their professional identity differently.

In two studies, the purpose was to test specific hypotheses. Moore and Hofman (1988) hypothesized that a strong professional identity would block the tendency of teachers to leave their jobs (in higher education), although the institutes in which they worked were considerably criticized. Gaziel (1995) hypothesized that there is an inverse correlation between teachers' professional identity and their job burnout levels, intentions of leaving the workplace, and intentions of leaving the profession. The purpose of Gaziel's study was to investigate the effect of a sabbatical year program on decreasing teachers' feelings of burnout and reducing their desire either to leave their own specific workplaces or to leave the profession entirely.

\subsection{Definition of professional identity}

Table 2 shows that, in six of the 11 studies, no explicit definition of professional identity was given. In the remaining studies, professional identity was defined in terms of teachers' sense or perceptions of their roles or relevant features of their profession, or in terms of their perceptions of themselves as an occupational group. An example of such a definition is that given by Moore and Hofman (1988) following a series of studies of social identity. They defined professional identity as follows (see also Table 2): 
(...) the extent to which someone thinks of his or her professional role as being important (Centrality), attractive (Valence), and in harmony with other roles (Consonance). Self Presentation and Solidarity are among further dimensions of professional identity (pp. 70-71).

The studies on teachers' perceptions of their roles or features of their profession vary in terms of the categories used in order to represent professional identity: from many concrete items in respect of which perceptions were scored to general and abstract notions about the profession which only in a general way indicate the kinds of perceptions the researchers were interested in (this will be discussed in more detail under the heading 'methodology').

\subsection{Related concepts}

Related concepts are hardly present in the studies. This may be due to the fact that most of the studies were not based on an explicit definition of professional identity. In most of the studies, professional identity was seen as similar to certain aspects, roles, or characteristics that are found relevant by teachers themselves or by others (i.e., the researchers) and about which teachers were asked to express their perceptions. In fact, these aspects, roles, or characteristics were used to represent professional identity, not as concepts related to the concept of identity itself.

\subsection{Methodology}

The nine empirical studies listed in Table 2 (two studies were theoretical analyses) vary in the methodology used. In some studies survey questionnaires were used, varying from a very prestructured to a very unstructured way of questioning. In most of the studies, use was made of structured or semi-structured open-ended interviews with a limited number of teachers. Therefore, most of the studies can, like the studies on professional identity formation, best be characterized as small-scale and in-depth. In some studies, data were collected from different sources (e.g.,
Graham \& Young, 1998; Paechter \& Head, 1996). Like the studies on professional identity formation, the studies listed in Table 2 differ in the way and the extent to which they explain and account for the methods used. This is particularly true of the analysis of the data.

\subsection{Major findings}

A shared sense or perception of professional identity is hard to identify in the studies on aspects of teachers' professional identity. The absence of a shared sense of professional identity in these studies is somewhat in contrast to the findings of Nixon (1996), who concluded that (university) teachers' profess and practice values as an occupational group with a coherent professional perspective on teaching and learning.

The results of the studies related to specific issues are hard to compare. Taking again the study by DeCorse and Vogtle (1997) on men choosing to enter elementary education as an example, it was concluded that the most common reason for a male teacher to be or become an elementary teacher is the direct contact with and nurturing of children. In this, they do not differ from female teachers. Another finding concerning a specific issue was reported by Paechter and Head (1996) in their study on teachers' professional identity related to teaching low-status subjects. Teachers who teach such subjects tend to locate their professional identity in teaching in general rather than in their subject skills.

Experienced teachers seem to perceive relevant aspects of their profession (such as their interaction with students and their commitment to serving students) as positive (e.g., Beijaard, 1995). A teacher's positive self-perception of his or her professional identity appears to override his or her dissatisfaction with poor working conditions (Moore \& Hofman, 1988). Measures taken to improve teachers' working conditions may influence teachers' perceptions of their professional identity positively (Gaziel, 1995). Moore and Hofman (1988), e.g., found that striving for quality by the school is consistent with a highly developed professional identity. 


\section{Stories that (re)present professional identity}

This category consists of only two publications that fit our selection criteria. Both emphasize, more than those about teachers' professional identity formation, the influence of teachers' professional landscape on their professional lives. Connelly and Clandinin (1999) see this landscape as a storied landscape. During the last two decades, the narrative research tradition gained much influence on research on teaching and teacher education. Generally speaking, from a narrative perspective, the practice of teaching is seen as constructed when teachers tell and live out particular stories (Elbaz-Luwisch, 2002).

The studies, particularly that of Connelly and Clandinin (1999), explicitly relate storytelling to teachers' (and researchers' as well as administrators') professional identity. In the studies on teachers' professional identity formation presented above this relationship remained much more implicit. In Table 3 both studies that focused on teachers' stories that (re)present professional identity are summarized. Because of the limited

Table 3

Overview of the studies on stories that (re)present professional identity

\begin{tabular}{|c|c|c|c|c|c|}
\hline Author and year & $\begin{array}{l}\text { Purpose of the } \\
\text { study }\end{array}$ & Definition of p.i. & Related concepts & Methodology & Major findings \\
\hline Brooke (1994) & $\begin{array}{l}\text { To tell about the } \\
\text { process the teacher } \\
\text { went through in } \\
\text { coming to identify } \\
\text { herself as a } \\
\text { professional }\end{array}$ & $\begin{array}{l}\text { No explicit } \\
\text { definition; p.i. is } \\
\text { similar to being a } \\
\text { professional who is } \\
\text { partially defined by } \\
\text { the profession and } \\
\text { partially defined by } \\
\text { the teacher him/ } \\
\text { herself through } \\
\text { interaction with it }\end{array}$ & None & $\begin{array}{l}\text { One teacher told } \\
\text { and published her } \\
\text { personal story of } \\
\text { her development } \\
\text { toward } \\
\text { professionalism }\end{array}$ & $\begin{array}{l}\text { Becoming a } \\
\text { professional } \\
\text { implies dialogue } \\
\text { and learning } \\
\text { from experience } \\
\text { - Professionalism } \\
\text { in teaching is } \\
\text { recognizable but } \\
\text { should not lead } \\
\text { to an alienation } \\
\text { of professionals } \\
\text { from lay persons } \\
\text { (i.e., parents) }\end{array}$ \\
\hline $\begin{array}{l}\text { Connelly and } \\
\text { Clandinin (1999) }\end{array}$ & $\begin{array}{l}\text { To show the } \\
\text { interconnectedness } \\
\text { of knowledge, } \\
\text { context, and } \\
\text { identity in the } \\
\text { stories of teachers } \\
\text { and administrators }\end{array}$ & $\begin{array}{l}\text { p.i. is referred to as } \\
\text { 'stories to live by', } \\
\text { given meaning by } \\
\text { the narrative } \\
\text { understandings of } \\
\text { knowledge and } \\
\text { context }\end{array}$ & Shifting selves & $\begin{array}{l}\text { Teachers and } \\
\text { administrators } \\
\text { told, listened, } \\
\text { and responded } \\
\text { to each others' } \\
\text { stories } \\
\text { represented in a } \\
\text { book and } \\
\text { authored by } \\
\text { themselves } \\
\text { In the same } \\
\text { book, the } \\
\text { researchers } \\
\text { interpreted what } \\
\text { mattered to the } \\
\text { teachers and } \\
\text { administrators } \\
\text { without any } \\
\text { preset agenda or } \\
\text { intellectual } \\
\text { framework }\end{array}$ & $\begin{array}{l}\text { - Institutional } \\
\text { stories (i.e., a } \\
\text { prescribed } \\
\text { curriculum) are } \\
\text { crucial } \\
\text { influences on p.i. } \\
\text { - Teachers } \\
\text { respond } \\
\text { differently to } \\
\text { these stories } \\
\text { Matters of p.i. } \\
\text { are interwoven } \\
\text { with spatial and } \\
\text { temporal } \\
\text { borders on the } \\
\text { professional } \\
\text { landscape }\end{array}$ \\
\hline
\end{tabular}


number of studies, this table is explained and interpreted briefly below.

\subsection{Purpose of the studies}

In both studies, teachers' professional identity was presented in the stories they told and wrote. Connelly and Clandinin (1999) related professional landscape to two fundamentally different places with their own stories: the in-classroom place and the out-of-classroom place (see also Craig, 1998). In their research on teachers' personal practical knowledge, these authors (e.g., Clandinin \& Connelly, 1996; Connelly \& Clandinin, 1990) increasingly noticed that teachers' answers to their questions about knowledge seemed to be answers to questions about identity. They discovered that teachers were more concerned about who they were than about what they knew. This can also be recognized in the publication of Brooke (1994): in her story about her journey toward professionalism, she writes in particular about how she has become who she is and who she is now.

\subsection{Definition of professional identity}

While the study by Brooke (1994) did not have an explicit definition of professional identity, Connelly and Clandinin (1999) referred to professional identity in terms of 'stories to live by'. A story to live by, according to the authors, provides a narrative thread or story-line that educators draw on to make sense of themselves and their practice. 'Stories to live by' is a way to conceptually bring together a teacher's personal practical knowledge, his or her professional knowledge landscape, and identity (see also Clandinin, 2003). Through storytelling, teachers engage in narrative 'theorizing' and, based on that, teachers may further discover and shape their professional identity resulting in new or different stories (see also Bullough, 1997). These stories are in part personal stories shaped by their own knowledge, values, feelings, and purposes; they are also collective stories shaped by the traditions of the school where the teacher works and, though somewhat implicit in the work of Connelly and
Clandinin, the broader social, cultural, and historical context within which the stories are lived out (Elbaz-Luwisch, 2002).

\subsection{Related concepts}

In the work of Connelly and Clandinin the concept of 'shifting selves' (p. 131) appears to be important. Owing to changes in the educational landscape (e.g., changes in programs and curricula), teachers' identities (but also those of teacher educators and researchers) change as well and, it seems, this is often accompanied by tensions and dilemmas.

\subsection{Methodology}

Stories are (re)presented in both publications. Based on the work of Connelly and Clandinin (1999), it can be said that understanding practice in narrative terms cannot be separated from the development of self and identity. According to Phelan (2000), who reviewed this work of Connelly and Clandinin, story amplifies the relationship between what we believe and how we practice. In neither study was a theoretical framework used for the interpretation of the stories.

\subsection{Major findings}

Brooke (1994) described her process of becoming a teacher in terms of a person 'who teaches preschool' toward 'being a preschool teacher'. According to her, a professional has a certain body of assimilated knowledge in the field in which he or she works and the skill to use it effectively. Becoming a professional is for Brooke a process of interaction between what is found relevant by others in the vocation and what teachers value themselves. This implies a growth process characterized by learning from experiences and engaging in dialogue about these experiences with colleagues. Brooke pointed to issues of disagreement among colleagues which can lead to growth places. The stories in the work of Connelly and Clandinin (1999) give the reader a sense of what the narrators care about most, what motivates them, the conditions in which they carry out their 
work, and the dilemmas with which they live. These aspects of their professional lives usually remain hidden in a teaching life (Phelan, 2000). One such aspect is the relationship between identity and curriculum practice: when programs and curricula change, teachers lose a sense of themselves. School change, then, results in new stories to live by. However, teacher resistance against school change may also reflect an effort to maintain a story to live by. The tensions and dilemmas in the administrators' stories recounted by Connelly and Clandinin appear to be similar to those of teachers.

\section{Reconsidering research on teachers' professional identity}

In the introduction, we posed three questions. Based on the above review, we attempt to answer these questions in this section.

\subsection{Features of professional identity}

The concept of professional identity was defined differently or not defined at all in the studies we reviewed. The latter pertains particularly to the studies on teachers' characteristics of professional identity. These studies also showed much variety, ranging from the identification of characteristics that emerged from the data to teachers' perceptions of such characteristics that were already formulated by the researcher. On the basis of the studies on teachers' characteristics of professional identity, it is not possible to indicate which specific characteristics particularly shape teachers' professional identity. More indications of this can be derived from the studies on teachers' professional identity formation and the studies on stories that (re)present professional identity. Based on these studies, we identified the following features that, in our view, are essential for teachers' professional identity.

- Professional identity is an ongoing process of interpretation and re-interpretation of experiences (Kerby, 1991), a notion that corresponds with the idea that teacher development never stops and can be best seen as a process of lifelong learning (e.g., Day, 1999). From a professional development perspective, therefore, professional identity formation is, in our view, not only an answer to the question "Who am I at this moment?", which we posed in the introduction to this article, but also an answer to the question: "Who do I want to become?", which is in line with what Conway (2001) called the function of anticipatory reflection. Seeing professional identity as an ongoing process implies that it is dynamic, not stable or fixed.

- Professional identity implies both person and context. A teacher's professional identity is not entirely unique. Teachers are expected to think and behave professionally, but not simply by adopting professional characteristics, including knowledge and attitudes, that are prescribed. Teachers differ in the way they deal with these characteristics depending on the value they personally attach to them. Feiman-Nemser and Floden (1986), e.g., wrote that there is no one teaching culture in a school and that every teacher, though limited by the context, may to some extent develop his or her own teaching culture.

- A teacher's professional identity consists of $s u b$ identities that more or less harmonize. The notion of sub-identities relates to teachers' different contexts and relationships. Some of these sub-identities may be broadly linked and can be seen as the core of teachers' professional identity, while others may be more peripheral. It seems to be essential for a teacher that these sub-identities do not conflict, i.e., that they are well balanced. During initial teacher training, student teachers often experience such conflict (e.g., Volkmann \& Anderson, 1998). Experienced teachers may experience such conflict in cases of educational change or change in their immediate working environment (e.g., Connelly \& Clandinin, 1999). The more central a subidentity is, the more costly it is to change or lose that identity.

- Agency is an important element of professional identity, meaning that teachers have to be active in the process of professional development (Coldron \& Smith, 1999). This element of 
professional identity formation is in line with a constructivist view of learning, which means that learning - individually as well as in collaboration-takes place through the activity of the learner. There are various ways in which teachers can exercise agency, depending on the goals they pursue and the sources available for reaching their goals. In addition, it can be argued that professional identity is not something teachers have, but something they use in order to make sense of themselves as teachers. The way they explain and justify things in relation to other people and contexts expresses, as it were, their professional identity (Coldron \& Smith, 1999).

\subsection{Characterizing the research}

Researchers investigating the characteristics of teachers' professional identity must ask themselves to what extent their purposes fit in with how the concept of (professional) identity is generally defined. The above-mentioned features of professional identity (particularly its process and everchanging nature) may imply that characteristics of professional identity can only be identified at a general and abstract level (Dillabough, 1999), or that it is probably better to place this research under another heading, e.g., under the heading 'professional characteristics' (Tickle, 2000).

The studies on teachers' professional identity formation and the stories that (re)present professional identity can be characterized as small-scale and in-depth. They all more or less appeared to be studies on teachers' personal practical knowledge (e.g., Connelly \& Clandinin, 1985; Elbaz, 1983; Golombek, 1998). Clandinin (1992) defined this type of knowledge as " ... carved out of, and shaped by, situations; knowledge that is constructed and reconstructed as we live out our stories and retell and relive them through processes of reflection" (p. 125). Most studies on teachers' professional identity formation demonstrated or reconstructed ways in which teachers build their personal practical knowledge from experiences in practice. However, in most of these studies, the relationship between professional identity and personal practical knowledge was assumed but not explained. In the studies on stories that (re)present professional identity, particularly in that of Connelly and Clandinin (1999), this relationship was made explicit: the authors increasingly noticed that teachers' answers to their questions about knowledge seemed to be answers to questions about identity.

In the other, more general, literature (e.g., Bakhtin, 1981; Giddens, 1991), the emphasis is placed on the importance of narrative and dialogue in the construction of self. Though not made explicit in many of the studies reviewed above, this may also explain the relevance of stories or narratives in research on teachers' professional identity. This identity, then, is formed and reformed by the stories we tell and which we draw upon in our communications with others. In other words, stories inadvertently shape teachers and teaching; they are not only chosen and managed by their tellers alone, but are also expressions of cultural values, norms, and structures passed on by the tellers (Rex, Murnen, Hobbs, \& McEachen, 2002).

In some studies on teachers' professional identity formation, explicit attention was paid to the importance of teachers' contexts and to research-based knowledge of teaching, i.e., professional characteristics that are seen as relevant to teachers and that should have a role in identity formation as well (e.g., Sugrue, 1997). Doing justice to a teacher's context and the researchbased knowledge of teaching that is available is in line with the notion that teachers' stories constitute their 'core' identity, but, at the same time, that these stories are socially formed and informed (Gee, 2001). This notion about the influence of the context on teachers' professional identity is particularly reflected in the studies on stories that (re)present teachers' professional identity.

We argue, more than in most of the studies on professional identity formation and in line with the studies on stories that (re)present teachers' professional identity, that identity formation is a process of practical knowledge-building characterized by an ongoing integration of what is individually and collectively seen as relevant to teaching. Fig. 1, inspired by Jansz (1991), illustrates in more detail what we mean by this. In this figure, the unbroken 


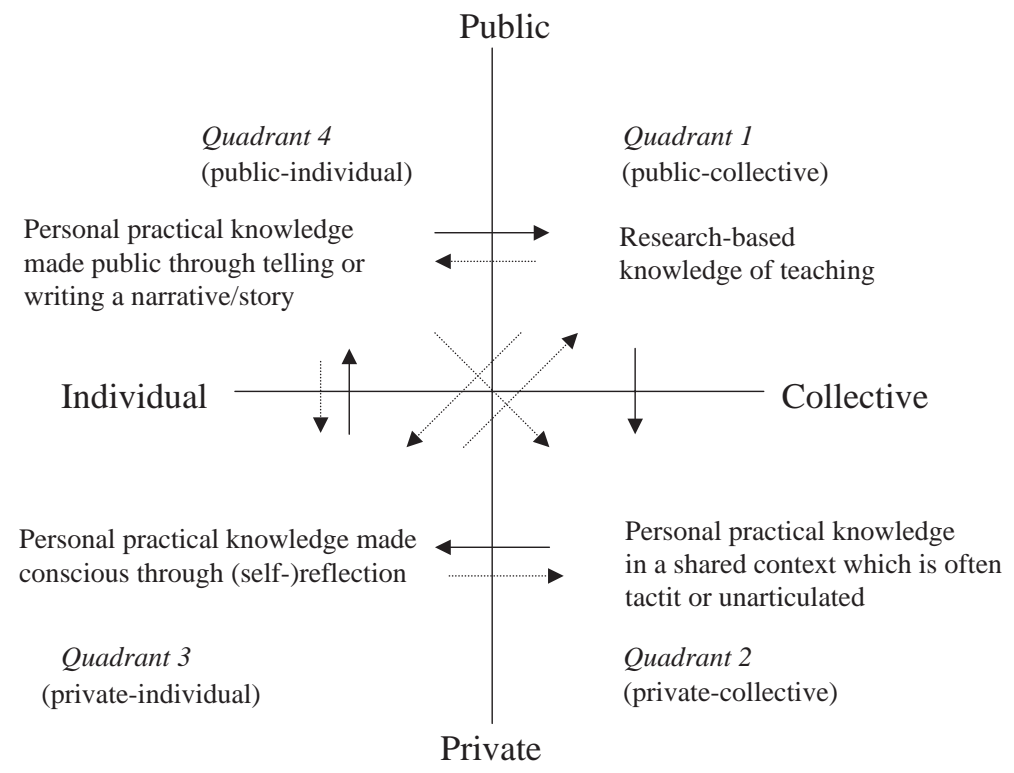

Fig. 1. Representation of professional identity formation from a teacher's knowledge perspective.

arrows represent the process of professional identity formation that is often seen as 'the' process by which teachers build their practical knowledge, beginning in Quadrant 1, passing through Quadrants 2, 3, and 4 and then again starting in Quadrant 1, etc. In reality, however, many other processes of identity formation also occur. These are represented by the broken arrows in Fig. 1. The studies on professional identity formation which we reviewed focused on the interaction between Quadrants 2 and 3 and on the results of this interaction (Quadrant 4), i.e., public accounts of (student) teachers' personal practical knowledge. Fig. 1 indicates that research on teachers' professional identity formation should focus on more ways of identity formation and that this process can be very complex. In the next section, we pay more attention to this.

\subsection{Problems that need to be addressed}

Based on the studies reviewed, we would like to point to the following problems. First, it remains unclear how exactly the concepts of 'identity' and 'self' are related. Both concepts were often used to indicate the same thing, but seem to be different concepts. According to Nias (1989), 'identity' forms part of 'self'. Through reflection, it can be argued, a person informs his or her identity, which may affect the self. This is in line with the work of Mead (1934), who made a distinction between ' $I$ ' and 'me' as two important components of 'self'. The 'I' is, so to say, the active component of self: through reflection, the 'I' articulates thoughts. 'Me' is the identity that the self develops. The 'me' owns those thoughts and recognizes, as it were, the voice of 'I' as its own (Miller, 1973). From this point of view the 'I' and 'me' cannot exist without each other. However, this is only one point of view. In order to define professional identity, it is important to make explicit from what point of view we see a teacher's self, because this determines how we see his or her professional identity. For example, from a modernist point of view, 'self' is strongly related to being authentic and fulfilling a pregiven individual autonomy, while from a post-modernist point of view, 'self' is strongly related to how people organize their experiences in stories, which may differ in time and depend on context (e.g., Edwards, 1997). The studies we reviewed seem to represent a mixture of modern and post-modern ways of looking at 'self'.

Second, in most of the studies on professional identity formation, the emphasis was on the 
'personal side' (the left side of Fig. 1) and less on the context and how the 'professional side' is seen in and by this context (the right side of Fig. 1). The need to pay explicit attention to the influence of the context (i.e., a teacher's landscape; Reynolds, 1996) on professional identity formation has been emphasized by Coldron and Smith (1999), Goodson and Cole (1994), and Connelly and Clandinin (1999). None of the studies, however, was explicit about the educational theories that are part of teachers' landscape as well and which also play a role in professional identity formation (see Fig. 1). Explicitly acknowledging this role of educational theories has implications for research. A structured though open method of data collection seems to be desirable. By using a 'structured' method, justice is done to what is contextually given and socially legitimated; by using an 'open' method, justice is done to the personal norms and values teachers themselves find important. It seems to us that the studies we reviewed did not sufficiently or explicitly take into account such (and other) methodological implications of research on teachers' professional identity.

Third, in Section 6.1, we mentioned four features of teachers' professional identity, but it remains unclear what counts as 'professional' in these features. These features may serve as a general framework on which to base professionality in teaching on and determine how a person can become a professional teacher. What counts as 'professional', then, is related to ways in which teachers relate to other people (students, colleagues, parents; see also Richardson \& Placier, 2001) and the responsibilities, attitudes, and behaviors they adopt as well as the knowledge they use which are, more or less, outside themselves. We argue that such aspects need to become common themes of research on teachers' professional identity. On the basis of the studies we reviewed, it is not yet possible to identify such common themes.

Fourth, and in addition to what was written above, a cognitive perspective underlies most studies on teachers' professional identity. From this perspective, the research results are based on written or verbal data collected from the teachers (e.g., portfolios and interviews). Understanding these data is only possible when data is also available about the teachers' contexts from a more sociological perspective, e.g., gained through (participant) observation and analysis of school documents and student materials. Furthermore, a teacher's biography is important for professional identity formation (e.g., Knowles, 1992; Sugrue, 1997). In the literature on teachers and teaching, 'biography' seems to imply a perspective of its own, with the emphasis on life histories (Goodson, 1992; Kelchtermans, 1994). Life histories are not just 'life stories', but stories that are embedded in a socio-historical context. The cognitive and the biographical perspectives on professional identity formation are both characterized by a narrative research approach. This cannot be said about the sociological perspective, though it is implied in the biographical perspective. In view of professional identity formation, we feel that more clarity is needed about these perspectives that can possibly be combined in research on teachers' professional identity.

\section{Conclusion}

In the introduction, we identified teachers' professional identity as an emerging research area, particularly in the last decade. The number of studies available for the present review was limited, so that we consulted additional studies. The information we acquired from this additional group of studies was added to findings based on the studies we systematically analyzed. It can be concluded that, in most studies, the concept of professional identity was defined differently or not defined at all. The latter pertains particularly to the studies on characteristics of teachers' professional identity, a line of research we suggest should be placed under a heading other than that of 'professional identity'.

The concept of teachers' professional identity was defined most explicitly in studies on professional identity formation (e.g., Coldron \& Smith, 1999; Goodson \& Cole, 1994; Sugrue, 1997; Volkmann \& Anderson, 1998) and in studies on stories that (re)present professional identity, i.e., the work of Connelly and Clandinin (1999). Both categories of studies overlap in the sense that, in 
both, the emphasis was placed on personal practical knowledge. Differences between these categories of studies pertain to the influence of teachers' context ('landscape') on shaping professional identity and the relationship identified between teachers' personal practical knowledge, i.e., stories or narratives, and professional identity. This relationship between teachers' stories and their professional identity is in line with the other, more general, literature (e.g., Bakhtin, 1981; Gee, 2001; Giddens, 1991) and seems to be a sound theoretical basis for researching teachers' professional identity.

Based on the studies reviewed, we identified four features that, in our view, are essential for professional identity. They may function as a general framework for future research on teachers' professional identity. The current research on teachers' professional identity is not without problems. Different concepts were used to indicate the same thing, or it was not clarified how they are related; this pertains particularly to the concepts of 'self' and 'identity'. We argued for better conceptual clarity of these concepts. We also argued that more attention should be paid to the role of context in professional identity formation and to what counts as professional in teachers' professional identity. In our opinion, the 'professional landscape' metaphor (Connelly \& Clandinin, 1999) may offer a perspective for this: teachers are part of this landscape, as are 'relevant others' (researchers, policy makers, school administrators, teacher educators, etc.) who represent different aspects of the landscape. We believe that a permanent dialogue between these actors in the professional landscape may lead to a better insight into what counts as professional in teachers' professional identity.

\section{References}

Antonek, J. L., McCormick, D. E., \& Donato, R. (1997). The student teacher portfolio as autobiography: Developing a professional identity. Modern Language Journal, 81(1), 15-27.

Bakhtin, M. M. (1981). The dialogic imagination: Four essays by M.M. Bakhtin. Austin, TX: University of Texas Press.
Beijaard, D. (1995). Teachers' prior experiences and actual perceptions of professional identity. Teachers and Teaching: Theory and Practice, 1(2), 281-294.

Beijaard, D., Verloop, N., \& Vermunt, J. D. (2000). Teachers' perceptions of professional identity: An exploratory study from a personal knowledge perspective. Teaching and Teacher Education, 16, 749-764.

Brooke, G. E. (1994). My personal journey toward professionalism. Young Children, 49(6), 69-71.

Bullough, R. V. (1997). Practicing theory and theorizing practice. In J. Loughran, \& T. Russell (Eds.), Purpose, passion and pedagogy in teacher education (pp. 13-31). London: Falmer Press.

Bullough, R. V., Knowles, G., \& Crow, N. A. (1992). Emerging as a teacher. London, New York: Routledge.

Clandinin, D. J. (1992). Narrative and story in teacher education. In T. Russell, \& H. Munby (Eds.), Teachers and teaching: From classroom to reflection (pp. 124-137). Sussex: Falmer Press.

Clandinin, D. J. (2003). Stories to live by on landscapes of diversity: Interweaving the personal and professional in teachers' lives. Key note paper presented at the 11th conference of the International Study Association on Teachers and Teaching (ISATT). Leiden, The Netherlands.

Clandinin, D. J., \& Connelly, F. M. (1996). Teachers' professional knowledge landscapes: Teacher stories-stories of teachers-school stories-stories of schools. Educational Researcher, 25(3), 24-30.

Coldron, J., \& Smith, R. (1999). Active location in teachers' construction of their professional identities. Journal of Curriculum Studies, 31(6), 711-726.

Connelly, F. M., \& Clandinin, D. J. (1985). Personal practical knowledge and the modes of knowing. In E. Eisner (Ed.), Learning and teaching the ways of knowing (pp. 174-198). Chicago: University of Chicago Press.

Connelly, F. M., \& Clandinin, D. J. (1990). Stories of experience and narrative inquiry. Educational Researcher, 19(5), 2-14.

Connelly, F. M., \& Clandinin, D. J. (1999). Shaping a professional identity: Stories of education practice. London, ON: Althouse Press.

Conway, P. (2001). Anticipatory reflection while learning to teach: From a temporally truncated to a temporally distributed model of reflection in teacher education. Teaching and Teacher Education, 17, 89-106.

Cooper, K., \& Olson, M. R. (1996). The multiple 'I's' of teacher identity. In M. Kompf, W. R. Bond, D. Dworet, \& R. T. Boak (Eds.), Changing research and practice: Teachers' professionalism, identities and knowledge (pp. 78-89). London/Washington, DC: The Falmer Press.

Craig, C. J. (1998). The influence of context on one teacher's interpretive knowledge of team teaching. Teaching and Teacher Education, 14, 371-383.

Day, C. (1999). Developing teachers, the challenge of lifelong learning. London, Philadelphia: Falmer Press.

DeCorse, C. J. B., \& Vogtle, S. P. (1997). In a complex voice: The contradictions of male elementary teachers' career 
choice and professional identity. Journal of Teacher Education, 48(1), 37-46.

Dillabough, J. A. (1999). Gender politics and conceptions of the modern teacher: Women, identity and professionalism. British Journal of Sociology of Education, 20(3), 373-394.

Edwards, R. (1997). Changing places? Flexibility, lifelong learning and a learning society. London: Routledge.

Elbaz, F. (1983). Teacher thinking: A study of practical knowledge. London: Croom Helm.

Elbaz-Luwisch, F. (2002). Writing as inquiry: Storying the teaching self in writing workshops. Curriculum Inquiry, 32, 403-428.

Erikson, E. H. (1968). Identity, youth and crisis. New York: W.W. Norton \& Company.

Feiman-Nemser, S., \& Floden, R. E. (1986). The cultures of teaching. In M. C. Wittrock (Ed.), Handbook of research on teaching (pp. 505-526). New York: Macmillan.

Gaziel, H. H. (1995). Sabbatical leave, job burnout and turnover intentions among teachers. International Journal of Lifelong Education, 14(4), 331-338.

Gee, J., \& Crawford, V. (1998). Two kinds of teenagers: Language, identity, and social class. In D. Alvermann, K. Hinchman, D. Moore, S. Phelps, \& D. Waff (Eds.), Reconceptualizing the literacies in adolescents' lives (pp. 225-245). Mahwah, NJ: Erlbaum.

Gee, J. P. (2001). Identity as an analytic lens for research in education. In W. G. Secada (Ed.), Review of research in education, Vol. 25 (pp. 99-125). Washington, DC: American Educational Research Association.

Giddens, A. (1991). Modernity and self-identity: Self and society in the late modern age. Cambridge, UK: Polity Press.

Golombek, P. R. (1998). A study of language teachers' personal practical knowledge. TESOL Quarterly, 32(2), 447-464.

Goodson, I. (Ed.) (1992). Studying teachers' lives. London: Routledge.

Goodson, I. F., \& Cole, A. L. (1994). Exploring the teacher's professional knowledge: Constructing identity and community. Teacher Education Quarterly, 21(1), 85-105.

Graham, R., \& Young, J. (1998). Curriculum, identity, and experience in multicultural education. The Alberta Journal of Educational Research, 44(4), 397-407.

Jansz, J. (1991). Person, self, and moral demands. Leiden University: DSWO Press.

Jeans, B. A. (1996). The construction of professional identity. International Journal of Psychology, 31(3/4), 224.201.

Kelchtermans, G. (1994). De professionele ontwikkeling van leerkrachten basisonderwijs vanuit het biografisch perspectief (The professional development of elementary teachers from the biographical perspective). Leuven: University Press.

Kerby, A. (1991). Narrative and the self. Bloomington, IN: Indiana University Press.

Knowles, G. J. (1992). Models for understanding pre-service and beginning teachers' biographies: Illustrations from case studies. In I. F. Goodson (Ed.), Studying teachers' lives (pp. 99-152). London: Routledge.

Kompf, M., Bond, W. R., Dworet, D., \& Boak, R. T. (Eds.) (1996). Changing research and practice: Teachers' profes- sionalism, identities and knowledge. London, Washington, DC: Falmer Press.

Korthagen, F. A. J. (2001). Waar doen we het voor? Op zoek naar de essentie van goed leraarschap (What are we doing it for? Searching for the essence of good teaching). University of Utrecht: IVLOS.

Mawhinney, H., \& Xu, F. (1997). Restructuring the identity of foreign-trained teachers in Ontario schools. TESOL Quarterly, 31(3), 632-639.

McCarthey, S. J. (2001). Identity construction in elementary readers and writers. Reading Research Quarterly, 36(2), 122-151.

McCormick, C. B., \& Pressley, M. (1997). Educational psychology: Learning, instruction, assessment. New York: Longman.

Mead, G. J. (1934). Mind, self and society. Chicago: University of Chicago Press.

Mertens, D. M. (1998). Research methods in education and psychology. Thousand Oaks, London, New Delhi: Sage.

Miller, D. (1973). George Herbert Mead. Self, language and the world. Chicago: University of Chicago Press.

Mishler, E. G. (1999). Storylines: Craft artists' narratives of identity. Cambridge, MA: Harvard University Press.

Mitchell, A. (1997). Teacher identity: A key to increased collaboration. Action in Teacher Education, 19(3), 1-14.

Moore, M., \& Hofman, J. E. (1988). Professional identity in institutions of higher learning in Israel. Higher Education, 17(1), 69-79.

Nias, J. (1989). Teaching and the self. In M. L. Holly, \& C. S. McLoughlin (Eds.), Perspective on teacher professional development (pp. 151-171). London: Falmer Press.

Nixon, J. (1996). Professional identity and the restructuring of higher education. Studies in Higher Education, 21(1), 5-16.

Paechter, C., \& Head, J. (1996). Gender, identity, status and the body: Life in a marginal subject. Gender and Education, 8(1), 21-29.

Phelan, A. M. (2000). A knot to unfurl (A book review of 'Shaping a professional identity: Stories of education practice' by M. F. Connelly \& D. J. Clandinin, 1999, London, ON: Althouse Press). Alberta Journal of Educational Research, 46, 288-290.

Preuss, E., \& Hofsass, Th. (1991). Integration in the Federal Republic of Germany: Experiences related to professional identity and strategies of teacher training in Berlin. European Journal of Teacher Education, 14(2), 131-137.

Purkey, W. W. (1970). Self-concept and school achievement. Englewood Cliffs, NJ: Prentice-Hall.

Rex, L. A., Murnen, T. J., Hobbs, J., \& McEachen, D. (2002). Teachers' pedagogical stories and the shaping of classroom participation: "The Dancer" and "Graveyard Shift at the 711". American Educational Research Journal, 39, 765-796.

Reynolds, C. (1996). Cultural scripts for teachers: Identities and their relation to workplace landscapes. In M. Kompf, W. R. Bond, D. Dworet, \& R. T. Boak (Eds.), Changing research and practice: Teachers' professionalism, identities and knowledge (pp. 69-77). London, Washington, DC: The Falmer Press. 
Richardson, V., \& Placier, P. (2001). Teacher change. In V. Richardson (Ed.), Handbook of research on teaching (pp. 905-947). Washington, DC: American Educational Research Association.

Roberts, L. (2000). Shifting identities: An investigation into student and novice teachers' evolving professional identity. Journal of Education for Teaching, 26(2), 185-186.

Samuel, M., \& Stephens, D. (2000). Critical dialogues with self: Developing teacher identities and roles - a case study of South Africa. International Journal of Educational Research, 33(5), 475-491.

Siraj-Blatchford, I. (1993). Educational research and reform: Some implications for the professional identity of early years teachers. British Journal of Educational Studies, 41(4), 393-408.

Sugrue, C. (1997). Student teachers' lay theories and teaching identities: Their implications for professional development. European Journal of Teacher Education, 20(3), 213-225.

Taylor, C. (1989). Sources of the self: The making of the modern identity. Cambridge, MA: Harvard University Press.

Tickle, L. (2000). Teacher induction: The way ahead. Buckingham, Philadelphia: Open University Press.

Volkmann, M. J., \& Anderson, M. A. (1998). Creating professional identity: Dilemmas and metaphors of a first-year chemistry teacher. Science Education, 82(3), 293-310. 